\title{
Experimental Simulation of Dam on Soil with Cavity for Measuring Uplift Pressure Force
}

\author{
Laith Jawad Aziz and Mohammed Shaker Mahmood \\ Department of Civil Engineering, College of Engineering, University of Kufa, Kufa, Iraq
}

\begin{abstract}
Experimental investigation is performed to simulate the forces acting on the dam (vertical uplift upward and lateral thrust toward the downstream side). The dams depending mainly upon its own weight to resist these effects, therefore, the prediction of the uplift pressure force is of great significance in the dam stability and safe, especially when the foundation soil contains. Forty two model test are conducted by using steel dam with sheet pile at various positions (dam heel, at mid floor of dam and at dam toe) resting on sandy soil with artificially cavity at a different locations in $\mathrm{X}$ and $\mathrm{Z}$ directions (lateral cavity location, $\mathrm{X}$ ) and (cavity depth, D) through the flow region. It was concluded that generally, the values of the pressure head under the floor of the dam with cavity conditions are greater than that for no cavity condition. To reduce the magnitudes of the generated uplift pressure force due to the presence of the cavity, the sheetpile must be installed in the dam center. The effects of the cavity depth on the safe dam depends on the regions of sheetpile placed, (the critical positions of the sheetpile are at the dam toe and at the dam heel when the cavity locations are in deep and shallow, respectively).
\end{abstract}

Key words: Uplift pressure, seepage, sandy soil, cavity, dam with sheetpile, dam toe

\section{INTRODUCTION}

The safety and stability of the hydraulic dam are related to with value of the uplift force, this is because of the great variety of the pressure heads of the water seepage under the dam that pushes the floor upward. In additional to, a horizontal thrust pressure force (due to water level in upstream) act on a dam, pushing the dam towards the downstream (the dam sliding). The moments may be generated by the uplift and water pressure, it's lead to the dam overturning.

The simulation of the dam as an experimental physical model tests is very difficult due to the limitations of loading techniques but the numerical model tests are easily applied to the dam (Liu et al., 2003). Rupture of a part of the dam floor may be occurred when the uplift pressure force is not counter balanced by the weight of the dam (Al-Delewy, 2006). As the hydraulic dam reservoir constructed in the complex foundation soil as in Al-Najaf topography (fluvial sediments, sabakha, sand dunes, eoline sediments, sand sheet, gypsum sediments and Limestone layers, the dam safety is decreasing. Groundwater that flows through pores and along fractures lines chemically erodes the limestone rock by solution. Large cavities in the limestone are formed as a result of concentrated groundwater flowing through areas where the underground limestone is more porous or has a higher solubility. The solution process continues enlarging these voids (Sweeney, 1986), therefore, the water is the most important factor the dam stability. The conditions of the presence of the cavity with water flow simulate actual conditions present in nature in AL-Najaf City.

Literature review: Many methods have been developed by several investigators for estimation of the effects of the pressure heads (uplift pressure) under dam and around sheet pile wall like empirical solution, numerical and experimental solution. The peak values of the uplift pressure are marked at the point just down stream of the dam when the water level in up and down stream of the dam are full (maximum) and zero (minimum), respectively. (Karim, 1988). Ghaly et al. (1991) founded that the uplift behavior of the sheet pile and seepage quantity depended on soil properties.

The design charts for sheet piles downstream blanket systems are presented by Obaed (2008) to estimate maximum uplift head around upstream and downstream sheet piles, respectively, seepage discharge. The maximum uplift head acting on upstream and downstream sheet pile walls decreases with increasing of downstream blanket length. Chen et al. proposed an equivalent method for measuring uplift pressure in model of gravity dam. The results show that this method is a feasible test method for simulating the effects of the uplift pressure force. Al-Saadi et al. (2011) concluded that the influence of downstream cut-off inclination angle in reducing uplift pressure head under the hydraulic structure is very small.

Corresponding Author: Laith Jawad Aziz, Department of Civil Engineering, College of Engineering, University of Kufa, Kufa, Iraq 
The seepage flow under hydraulic structures with intermediate filter provided by Mcloughlin and Ahmed. It was found that introduction of an intermediate filter to the floor of the structure reduced the uplift force acting on the downstream floor by up to $72 \%$ compared with the case when no filter was in place. Obaed (2013) concluded that the uplift pressure head is decreased when the inclination of the cutoff wall is towards the downstream part of the dam. Shayan and Amiri Tokaldany (2015) founded that the best of cutoff wall to reduce the value of uplift force is at the upstream end. In recently, Nassralla and Rabea (2016) investigated the seepage characteristics under hydraulic structure foundation supported by sheet pile in multi-layers soil. From the result study the case of experimentally and numerically, can be included that to decrease the uplift pressure values under the hydraulic structure foundation can be installed sheet pile at the dam toe. Uday and Hasan (2016) studied the effect of the location of the drainage gallery under gravity dam on the uplift pressure force values for two models once with and without sheetpile. The optimum position of the drainage gallery, constructed beneath gravity dam is found at (horizontal location to dam width, $\mathrm{X}_{\mathrm{d}} / \mathrm{B}=0.167$ ) at which reduction in volume of the uplift pressures is maximum and equals about 0.494 .

Generally, this research is presented to reduce the risk of the cavity generation within foundation soil of dam by studding the suitable regions to install the sheetpile which it reducing the uplift pressure force (dam stability). Where all these factors were not studied in the previous researches. Finally, a rapid method (empirical equation) of assessing the increasing of the uplift pressure force due to the cavity formation at a certain location is presented in this study.

\section{MATERIALS AND METHODS}

Tools used: A steel box is used with dimensions of its width, length and height are 250,1000 and $1250 \mathrm{~mm}$, respectively. The box consists of three parts, the middle part is used to place compacted soil with thickness $(\mathrm{T}=600 \mathrm{~mm}$ ). While the outside compartments are used as reservoirs for upstream and downstream levels. Steel model solid dam was designed with dimensions (width, $B=300 \mathrm{~mm}$, height $200 \mathrm{~mm}$ and length $=$ width of steel box $=250 \mathrm{~mm}$ ), placed on the ground surface level $\left(D_{f}=0\right)$. The steel sheet pile length into soil mass is constant for all model tests $(S=200$ $\mathrm{mm})($ i.e., $\mathrm{S} / \mathrm{T}=1 / 3$ ). To simulate the cavity into sandy soil, $\mathrm{PVC}$ tube with diameter $(\mathrm{d}=150 \mathrm{~mm})($ i.e., $\mathrm{d} / \mathrm{b}=1 / 2)$ and length equal to the width of the steel box $(250 \mathrm{~mm})$ were used. The PVC pipe has a high number of very small holes in their bodies to allow the flow see page through it as shown in Fig. 1.

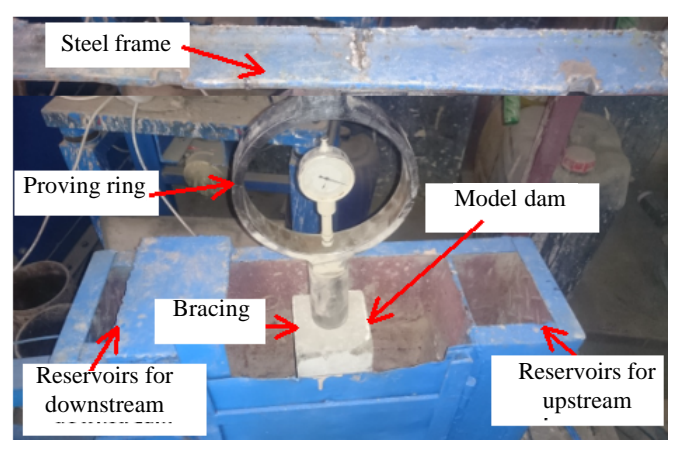

Fig. 1: Experimental model

Table 1: Phy sical and chemical properties of soil used

\begin{tabular}{ll} 
Properties & Values \\
\hline Physical properties & \\
Uniformity coefficient & 4.6 \\
Curvature coefficient & 1.1 \\
Specific gravity & 2.68 \\
Maximum dry density $\left(\mathrm{kN} / \mathrm{m}^{3}\right)$ & 18.1 \\
Optimum water content $(\%)$ & 7.2 \\
Coefficient of permeability k $(\mathrm{m} / \mathrm{sec})$ & $7.5^{*} 10^{5}$ \\
Plasticity index $(\%)$ & 6 \\
Cohesion $\left(\mathrm{kN} / \mathrm{m}^{2}\right)$ & 10 \\
Angle of shearing resistance & 39 \\
$\mathrm{Chemical} \mathrm{properties}$ & \\
$\mathrm{Gypsum}^{2}$ content\% & 0.76 \\
$\mathrm{SO}_{3} \%$ & 0.33 \\
$\mathrm{ORG} \%$ & 0 \\
$\mathrm{CaCo} \%$ & 0 \\
$\mathrm{TDS}(\mathrm{ppm})$ & 89 \\
$\mathrm{CL}(\mathrm{ppm})$ & 78 \\
$\mathrm{PH}$ & 7.85 \\
\hline
\end{tabular}

Soil used: Poorly graded sandy soil (Al-Najaf soil) is compacted in a steel box with a glass face in twelve layers to create a homogenous soil with unit weight and water content corresponding to maximum dry density and optimum water content (Very dense sand) by using a flat bottomed steel block. The physical and chemical properties of the soil used are listed in Table 1. During the compaction process, the cavity was placed at a certain location (X and D).

Testing model: After the completion of the compaction of the final layer, the model sheetpile pushing into the soil by handle jack with a constant rate of $(1.1 \mathrm{~mm} / \mathrm{sec})$ then the dam model fixed with sheetpile and it resting on the ground surface level. Seven piezometers were placed at a different locations under the dam to measure the pressure heads when the flow is as a steady state flow. To examine the reliability values of the uplift pressure force from the piezometer readings, the top of the dam are fixed with proving ring to measure the direct value of the actual 


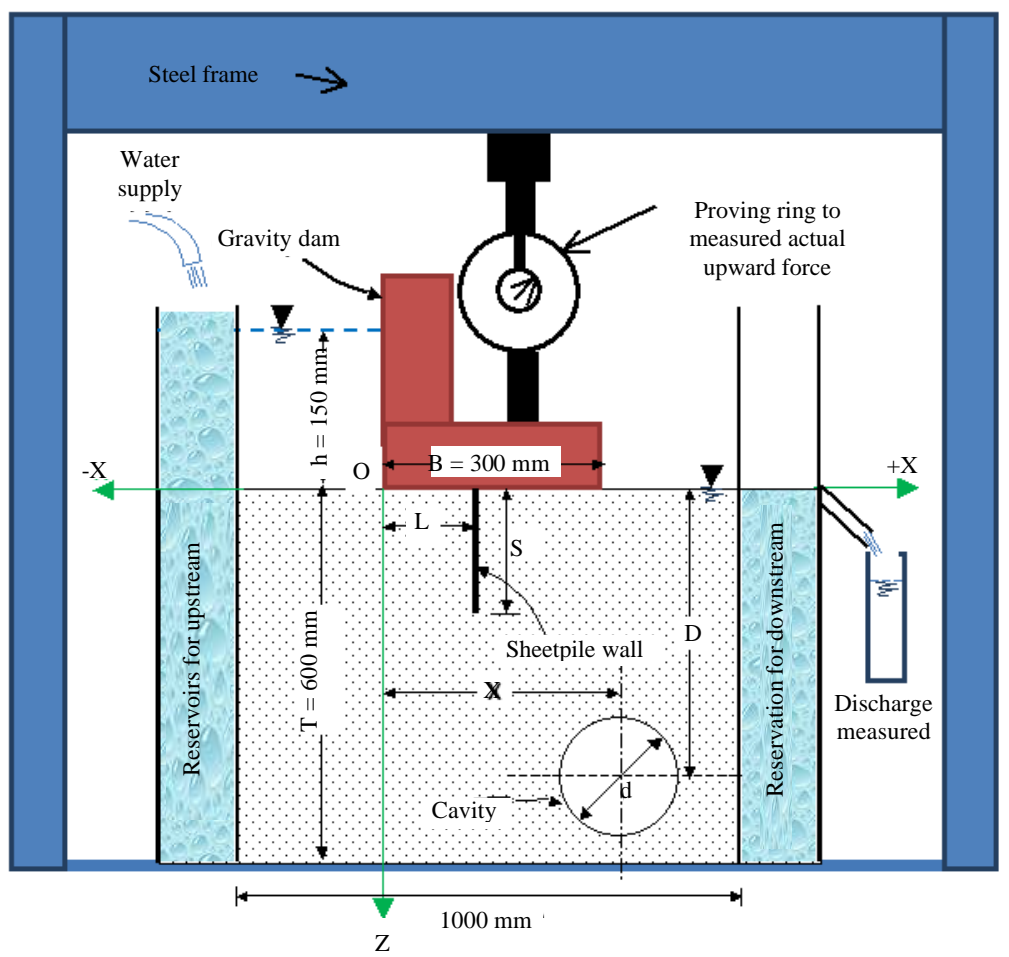

Fig. 2: Schematic diagram of the test preparation

upward force. Also, to prevent the dam sliding toward the downstream side and also to prevent the dam overturning due to the moments generated by the uplift and water pressure, the dam bracing in horizontal direction only. The water in upstream side was maintained at a constant level $(\mathrm{h}=150 \mathrm{~mm})$ during the testing period, the existing water from downstream was collected in a jar to measure the quantity of seepage. The schematic diagram of the test preparation shows the description of the parameters used such as water flowing, model cavity, model dam and sheet pile as shown in Fig. 2.

\section{RESULTS AND DISCUSSION}

The most of the available research do provide satisfactory estimates of the uplift force but not valid with the total actual upward force. The direct method used (by using a proving ring) in the research has been proposed to give consistently safe predictions during water flow till reach to steady state flow with very little scatter compare with the results of the uplift pressure force depending upon the pressure heads (by piezometers at different points) under the dam. The differences between the direct method (by proving ring) and by calculating pressure heads are very small ranged from $1.1-1.5 \%$.

In order to explain the effect of the cavity on the uplift pressure under the dam, the results are presented as a ratio of the uplift pressure of cavity to no cavity

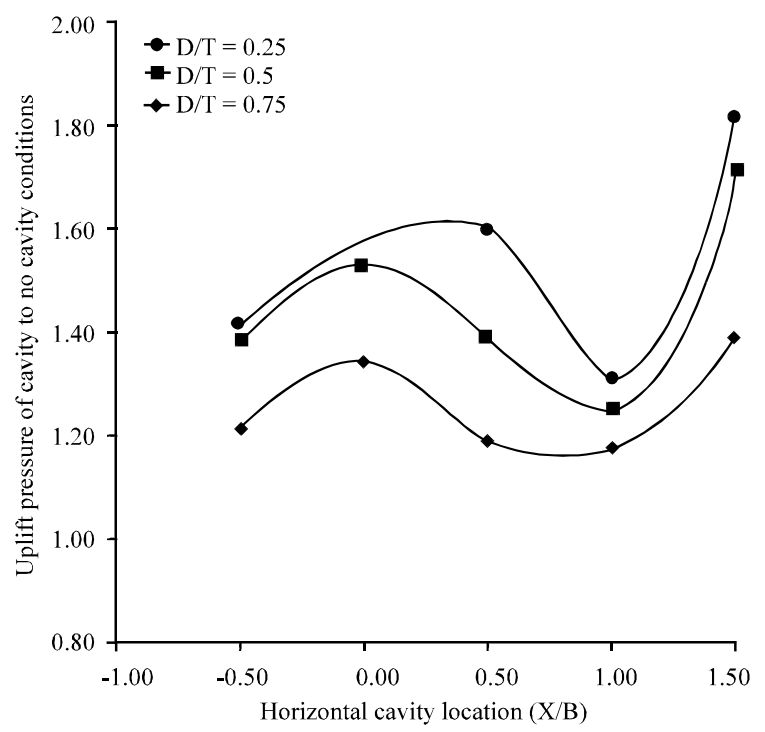

Fig. 3: Variation of $\left(\mathrm{P} / \mathrm{P}_{0}\right)$ ratio with $\mathrm{X} / \mathrm{B}$ at a various cavity depth when the sheetpile at dam heel

conditions $\left(\mathrm{P} / \mathrm{P}_{0}\right)$ for three locations of the sheetpile under the dam. Also, to facilitate the comparisons among the different model tests, all values of the parameters of the sheetpile and cavity are presented in terms the dimensionsless such as (Cavity depth, (D/T); horizontal location of cavity, (X/B) and Sheetpile location, (L/B). 


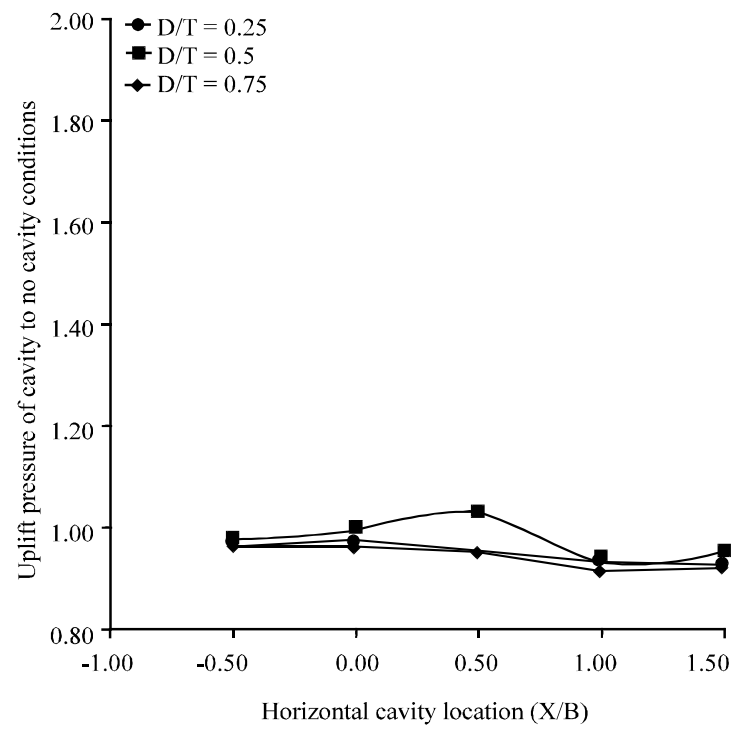

Fig. 4: $\left(\mathrm{P} / \mathrm{P}_{0}\right)$ ratio versus $\mathrm{X} / \mathrm{B}$ at a various cavity depth when the sheetpile at middle floor of the dam

Effect of cavity position on the developed uplift pressure under dam: Figure 3 shows the variations of the uplift pressure values of cavity at a certain location (X and D) to no cavity conditions $\left(\mathrm{P} / \mathrm{P}_{0}\right)$ when the sheetpile is installed at the dam heel. It is seen from the Fig. 3 that when the cavity were located at any depth $(\mathrm{D} / \mathrm{T})$ under the dam floor, the $\left(\mathrm{P} / \mathrm{P}_{0}\right)$ ratio decreases with variation of the horizontal location of cavity towards the downstream region (range of $(\mathrm{X} / \mathrm{B})$ from $0.0-1.0)$ but this behavior does not apply to the cavities which it is located outside the dam region, peak values of $\left(\mathrm{P} / \mathrm{P}_{0}\right)$ at $\mathrm{X} / \mathrm{B}>1.0$ and low values of $\left(\mathrm{P} / \mathrm{P}_{0}\right)$ at $\mathrm{X} / \mathrm{B}<0.0$.

The effects of the cavity in increasing values of the uplift pressure are high (ranging from $40-80 \%$ ) when it is location near the ground surface level, this is probably due to the fact that the presence of the sheetpile at the upstream side leaded to the rate of pushing of the water towards the shallow cavity is faster than that for the other cavity depths. Also, It is clear that the drop in a uplift pressure ratio $\left(\mathrm{P} / \mathrm{P}_{0}\right)$ can be observed with increasing cavity depth $(\mathrm{D} / \mathrm{T})$ to 0.75 , the increasing in uplift pressure force are equal to from $(20-40 \%)$.

In this study, the weight of the dam must be increased to resist the increasing of the generated uplift pressure force due to the cavity formation.

Relationships among cavity locations and the uplift pressure $\left(\mathrm{P} / \mathrm{P}_{0}\right)$ ratio for the case of the sheetpile at mid-floor dam are shown in Fig. 4. It is obvious from Fig. 4 that the uplift pressure values of cavity condition are smaller or equal to that the corresponding of no cavity conditions when the sheetpile is installed at the dam

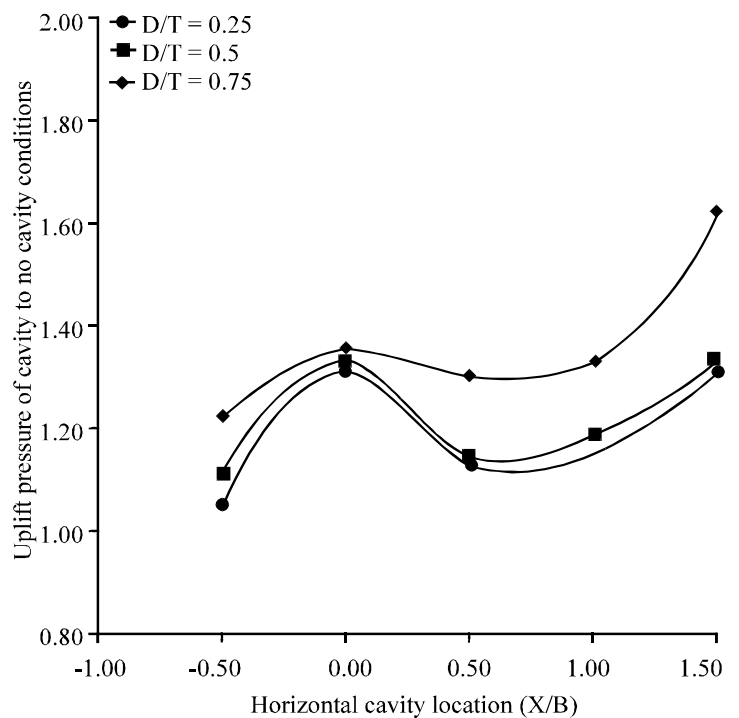

Fig. 5: Relationship between $\left(\mathrm{P} / \mathrm{P}_{0}\right)$ ratio with $\mathrm{X} / \mathrm{B}$ at a different cavity depth when the sheetpile at the dam heel

centerline. Therefore, in order to decrease the danger of the upward force and increasing the stability of the dam, the sheetpile must be placed in the middle of the dam.

The results of the $\left(\mathrm{P} / \mathrm{P}_{0}\right)$ ratio of the shallow and deep cavity location $(\mathrm{D} / \mathrm{T}=0.25$ and 0.75$)$ conditions are much close together although the case of $(\mathrm{D} / \mathrm{T}=0.25)$ recorded the highest values of the $\left(\mathrm{P} / \mathrm{P}_{0}\right)$ ratio. At any value of (D/T), a Slight effect of horizontal cavity location (X/B) on the uplift pressure can be noted. Also, it can be illustrated from Fig. 4, that the case of cavity at mid depth of the soil layer $(\mathrm{D} / \mathrm{T}=0.5)$ has a higher value of the $\left(\mathrm{P} / \mathrm{P}_{0}\right)$ ratio (i.e., high effect of the cavity on the uplift pressure), this is because of the location of the sheetpile is coincided with the centerline of the dam.

When the sheetpile is located at the dam toe, the $\left(\mathrm{P} / \mathrm{P}_{0}\right)$ ratio are plotted against the horizontal cavity location $(\mathrm{X} / \mathrm{B})$ at a various cavity depth $(\mathrm{D} / \mathrm{T})$ as shown in Fig. 5. The figure show that the effects of the deep cavity $(\mathrm{D} / \mathrm{T}=0.75)$ are high and it leaded to increase in uplift pressure force by $(22-64 \%)$. It is decreased with decreasing cavity depth to reach (4-30\%) at a shallow cavity $(\mathrm{D} / \mathrm{T}=0.25)$. In general, the values of the $\left(\mathrm{P} / \mathrm{P}_{0}\right)$ ratio of cavity location $\mathrm{X} / \mathrm{B}>1.0$ are a maximum and it becomes a minimum at $\mathrm{X} / \mathrm{B}<0$.

Slight effect of horizontal cavity location (from $\mathrm{X} / \mathrm{B}=0-1.0$ ) on the uplift pressure can be noted when the cavity is located in deep region ( $\mathrm{yc} / \mathrm{T}=0.75)$. The results of uplift pressure for the sheetpile at dam toe and heel have the same behavior trend for the model tests, except to the peak values of the $\left(\mathrm{P} / \mathrm{P}_{0}\right)$ of sheetpile toe can be observed at $(\mathrm{D} / \mathrm{T}=0.75)$ while of sheetpile heel are at $(\mathrm{D} / \mathrm{T}=0.25)$. 


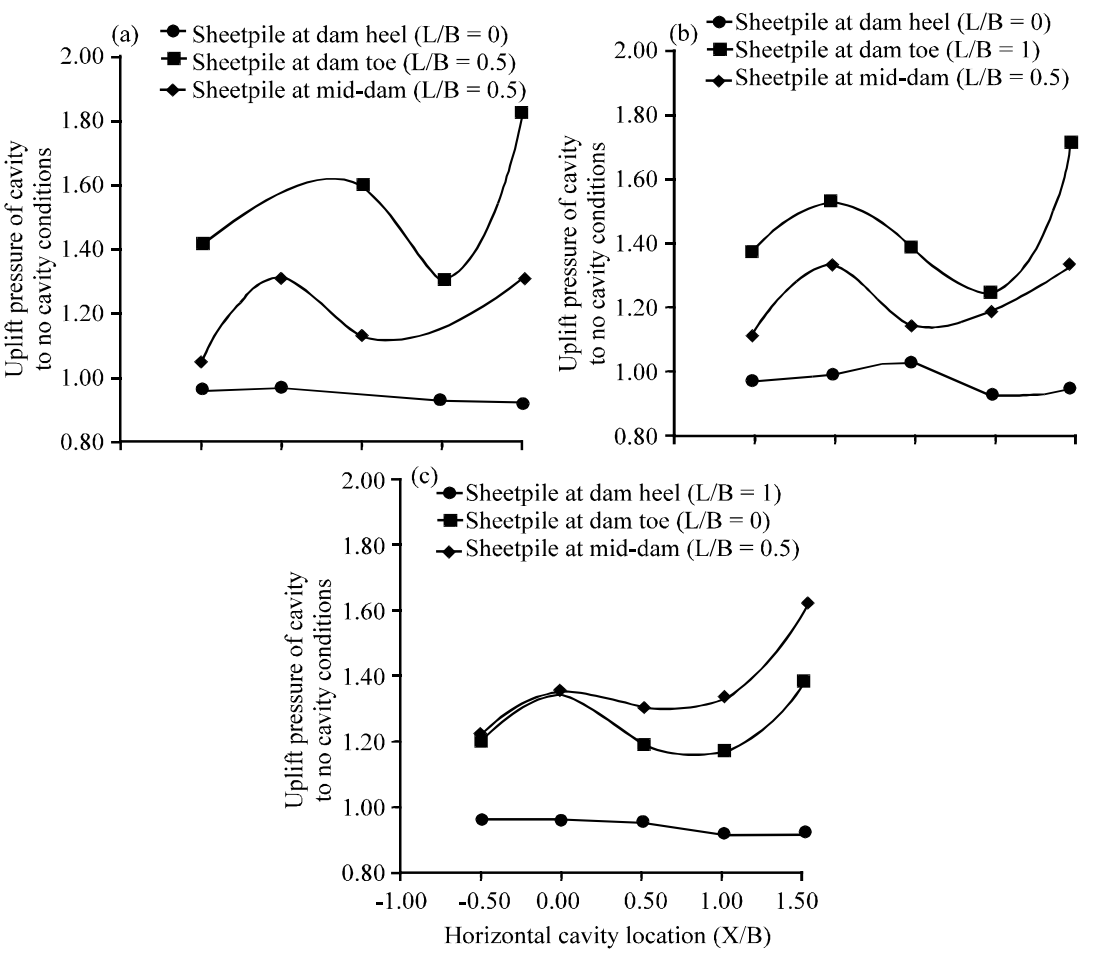

Fig. 6: Variation of the ratio of the uplift pressure of cavity to no cavity condition with sheetpile location; a) Cavity depth $(\mathrm{yc} / \mathrm{T}=0.25) ; \mathrm{b})$ Cavity depth $(\mathrm{yc} / \mathrm{T}=0.5)$ and $\mathrm{c})$ Cavity depth $(\mathrm{yc} / \mathrm{T}=0.5)$

Effect of sheetpile location on the generated uplift pressure under dam: Figure 6 a depicts the combined effect of the cavity and sheetpile location on the uplift pressure values when the cavity located near the ground surface level $(\mathrm{D} / \mathrm{T}=0.25)$. The values of the $\left(\mathrm{P} / \mathrm{P}_{0}\right)$ of the sheetpile at the dam heel are greater than that for it at dam middle or toe.

Figures $6 \mathrm{~b}$ show the variation values between the ratio $\left(\mathrm{P} / \mathrm{P}_{0}\right)$ and cavity location $(\mathrm{X} / \mathrm{B})$ when the model tests with cavity depth at the mid-thickness of the soil, $(\mathrm{D} / \mathrm{T}=$ 0.5 ) for three locations of sheet pile ( $\mathrm{B} / \mathrm{B}=0,0.5$ and 1 ) of the dam. It is observed that the peak values of ratio $\left(\mathrm{P} / \mathrm{P}_{0}\right)$ are recorded of the case of the sheetpile at the dam heel. The uplift pressure ratio $\left(\mathrm{P} / \mathrm{P}_{0}\right)$ under the dam are plotted as a function of a cavity location (X/B) at a deep cavity condition $(\mathrm{D} / \mathrm{T}=0.75)$ as shown in Fig. $6 \mathrm{c}$. It can noted that the sheetpile at toe dam case has a high values of $\left(\mathrm{P} / \mathrm{P}_{0}\right)$. Also, a slight effect of the horizontal cavity location on the uplift pressure values for all model tests.

Dam stability: Cavities in the limestone or in gypsum soil are formed as a result of concentrated groundwater flowing through areas where the underground is more

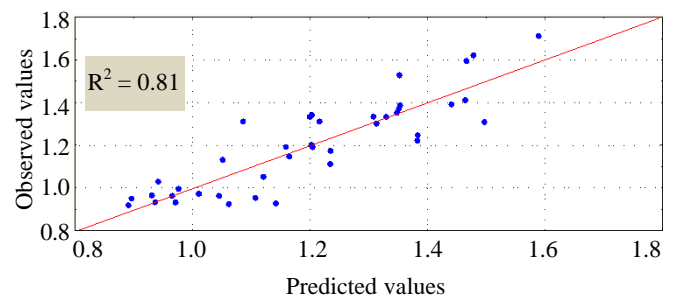

Fig. 7: Relationship between observed and predicted of $\mathrm{P} / \mathrm{P}$ 。

porous or has a higher solubility. The formation of the cavities lead to increase in the uplift pressure force values. From all these in stability of the dam may be occurred. In order to assess the effect of the increase in uplift pressure, the results are presented as a ratio of the values of the uplift pressure for cavity at a certain location to no cavity condition $\left(\mathrm{P} / \mathrm{P}_{0}\right)$.

Empirical Eq. 1 is resulted from a regression analysis by Ms-Statistica to estimate the increasing in uplift pressure due to the formation of the cavity at a certain location for any location of sheetpile with $\left(\mathrm{R}^{2}=0.81\right)$, (Fig. 7). Equation 1 can be applied on a large concrete dam to simulate the upward force: 


$$
\begin{aligned}
& \frac{\mathrm{P}}{\mathrm{PO}}=\left(\frac{\mathrm{D}}{\mathrm{T}}\right)^{\mathrm{c} 1} \times\left(\left(\frac{\mathrm{L}}{\mathrm{B}}\right)^{\mathrm{c} 1}-\frac{1}{2}\right)-\left(\frac{\mathrm{L}}{\mathrm{B}}\right)^{0.01} \times \\
& \left(\frac{\mathrm{X}}{14 \mathrm{~B}}+\frac{1}{2}\right)+\left(\frac{\mathrm{X}}{2 \mathrm{~B}}\right)^{5}+\mathrm{cl}
\end{aligned}
$$

where, the coefficient $C_{1}=1.525$. Figure 5 shows a well accepted correlation between predicted and observed $\left(\mathrm{P} / \mathrm{P}_{0}\right)$.

\section{CONCLUSION}

Generally, the values of the pressure head under the floor of the dam with cavity conditions are greater than that for no cavity condition. Highest and lowest of the $\left(\mathrm{P} / \mathrm{P}_{0}\right)$ ratio are selected when the cavities are located outside the dam region $(\mathrm{Xc} / \mathrm{B}<1.0)$ and $(\mathrm{Xc} / \mathrm{B}<0.0)$, respectively. The effects of the cavity depth on the safe dam depends on the sheetpile locations. High effect of the cavity depth $(\mathrm{D} / \mathrm{T}=0.25)$ is marked when the sheetpile is located at the dam heel, (i.e., the weight of the dam must be increased to $70 \%$ ). While at deep cavity, $\mathrm{D} / \mathrm{T}=0.75$, the sheetpile at dam toe is a danger position (i.e., the uplift pressure force increased by approximately $30 \%$.

For the three locations of sheetpile, the effects of the cavity on uplift pressure decreases with variation of (Xc/B) from 0.0-1.0. No effect of the cavity on the uplift pressure when the sheetpile is located at the centerline of the dam. (No need to increase the weight of the dam).

\section{RECOMMENDATIONS}

- Empirical Eq. 1 can be used on a practical dam resting on soil with cavity

- When the foundation soil under the dam contain a cavity, the sheetpile must be placed in the dam center

- For a shallow cavity case, the sheetpile must be placed at a dam toe but for a deep cavity case, the sheetpile must be placed at a dam heel

- The top of the dam must be fixed with proving ring to measure the actual upward force due to pressure heads under the dam

\section{REFERENCES}

Al-Delewy, A.A., A.H.K. Shuku and E.W.H. AL-Musawi, 2006. Optimum design of control devices for safe seepage under hydraulic structures. J. Eng. Dev., 10: 66-87.

Al-Saadi, S.I.K., H.T.N. Al-Damarchi and H.C.H. AlZrejawi, 2011. Optimum location and angle of inclination of cutoff to control exit gradient and uplift pressure head under hydraulic structures. Jordan J. Civil Eng., 5: 380-391.

Ghaly, A.M., A.M. Hanna and M. Hanna, 1991. Uplift behavior of screw anchors in sand. II: Hydrostatic and flow conditions. J. Geotech. Eng., 117: 773-793.

Karim, R.A., 1988. Variation of uplift pressure and exit gradient downstream of hydraulic structures. BSc Thesis, University of Baghdad, Baghdad, Iraq.

Liu, J., X.T. Feng, X.L. Ding, J. Zhang and D.M. Yue, 2003. Stability assessment of the Three-Gorges Dam foundation, China, using physical and numerical modeling-Part I: Physical model tests. Intl. J. Rock Mech. Min. Sci., 40: 609-631.

Nassralla, T.H. and A.R.M.A. Rabea, 2016. Seepage characteristics under hydraulic structure foundation (Supported by Sheet pile) in multi-layers soil. Egyptian Intl. J. Eng. Sci. Technol., 18: 229-238.

Obaed, I.H., 2008. Design Charts for Sheet PilesDownstream Blanket Systems. University of Babylon, Hillah, Iraq,

Obead, I.H., 2013. Effect of position and inclination angle of cutoff wall on seepage control in the foundation of dam structure. J. Kerbala Univ., 11: 17-32.

Shayan, H.K. and E. Amiri-Tokaldany, 2015. Effects of blanket, drains and cutoff wall on reducing uplift pressure, seepage and exit gradient under hydraulic structures. Intl. J. Civil Eng., 13: 486-500.

Sweeney, M., 1986. Ground penetrating radar in the detection of subsurface cavities related to sinkhole activity in Florida. MSc Thesis, University of Central Florida, Orlando, Florida.

Uday, A.M. and H.M. Hasan, 2016. Optimum location of drainage gallery under gravity dam by using finite element method. Intl. J. Multidiscip. Res. Mod. Educ., 2: 611-622. 